\title{
CONSIDERATIONS REGARDING THE IMPACT OF THE COVID-19 PANDEMICS OVER THE FINANCIAL PERFORMANCE AT THE LEVEL OF THE TOURISM COMPANIES OPERATING IN CENTRAL AND EASTERN EUROPE
}

\author{
Laurentiu DROJ', Gabriela DROJ² \\ ${ }^{1}$ University of Oradea, Faculty of Economics, Finance and Accounting \\ Department, Oradea, Romania \\ 2University of Oradea, Faculty of Construction, Cadaster and Architecture, \\ Oradea, Romania \\ Laurentiu.droj@uoradea.ro \\ Gdroj@uoradea.ro
}

\begin{abstract}
The tourism sector is one of the most dynamic economic sectors in Romania contributing with $6.3 \%$ in the number of workplaces and reaching $5.3 \%$ from the total GDP. The impact of the COVID-19 pandemic over this sector has been catastrophic. The goal of the proposed article is to perform a brief financial assessment of the companies operating in the tourism sector, located Romania, Croatia, Hungary and Slovenia, by using financial information collected from Amadeus database. The macroeconomic data was collected through Statista and the financial information used in the study is based on the financial reporting data for the years 2016-2020 processed through Amadeus data base. Based on both sets of data the current paper will attempt to analyze the financial information (ROE, ROA, annual return, evolution of cash-flow and number of employees) and determine if a link can be established between the evolution of the financial performance of the selected companies and the COVID-19 pandemics effects over the tourism sector. These companies were selected especially since they are extremely affected by the effects of COVID19 and therefore further research can be performed in the following years.
\end{abstract}

Keywords: financial analysis, financial results, ROE, ROA, Romania, Croatia, Slovenia, Hungary, COVID19, tourism

JEL classification: G32, G17, G34, O16

\section{Introduction}

The impact of the COVID-19 pandemic over the tourism sectors has been catastrophic. In a study published in 29 November 2021 by the United Nations citing UNWTO Barometer the projected lost revenues in 2021 for the tourism industry are in amount of 2 trillion USD (United Nations, 2021).

As it can be seen in a report published in November 2021 by UNWTO (2021) the number of tourist arrivals has collapsed in 2021 comparing with 2019 and in some regions even comparing with 2020 . 
Figure 12021 International Tourist Arrivals

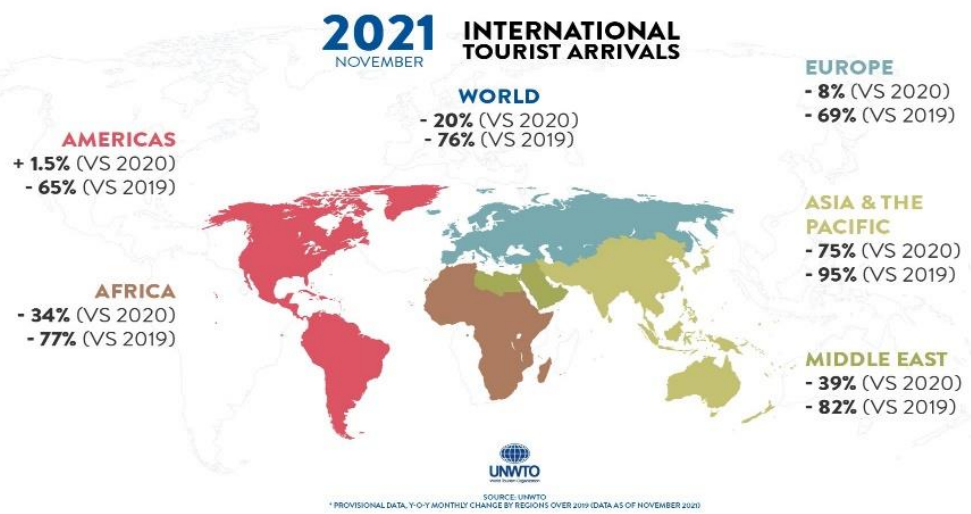

Source: UNWTO (2021) https://www.unwto.org/

For the Central and Eastern European Countries, the tourism sector is considered one of the most important economic sectors. A study published by Statista (2021) highlights the fact that Europe is the global leader in international tourism with a continuous tourism development, accruing over 700 million tourists each year and contributing to the European GDP growth with 2.191,2 billion USD. The total revenues from tourism decreased to $1.064,7$ billion USD in 2020, as an effect of COVID-19 pandemics.

The importance of this sectors is highlighted by the fact that is fastest developing economic sectors in Romania with a contribution of $6.3 \%$ of the total workplaces and a $5.3 \%$ direct contribution towards the GDP.s

Starting from the last financial crisis new elements have been introduced in the analysis since both academic researchers and audit agencies realized that, for a proper measurement of the phenomenon more financial and non-financial factors should be analysed. The results seem to be different from one case study to another and seems to be linked with the financial data at the disposal of the researchers (Droj and Tara, 2018, Ohlson, 1980 and Pierre, 2004).

Figure 2 Total contribution of travel and tourism to GDP in Europe

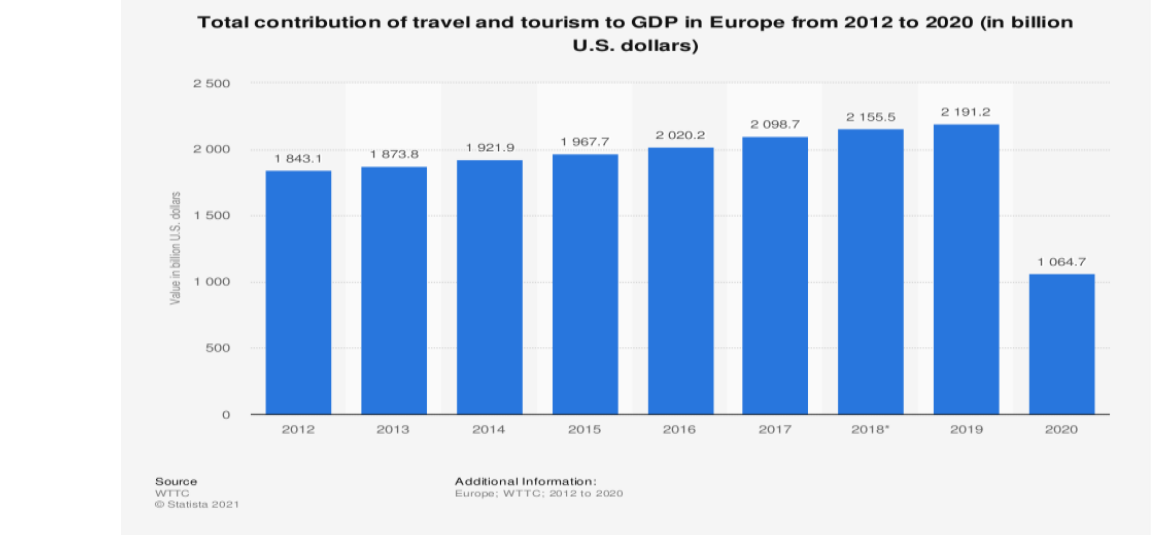

Source: Statista Research department

https://www.statista.com/statistics/617528/travel-tourism-total-gdp-contribution-europe/ 
Taken into consideration the above, the authors of this paper are trying to analyze several indicators, which can be highlight the impact of COVID over the financial performance of the tourism companies operating in Central and Eastern Europe. The authors selected several financial early warning indicators, which can be suitable for the proposed model. These are indicators including both classical liquidity or solvency indicators (Droj, 2012) and financial or economic efficiency indicators (Droj, 2015).

\section{Selection of the financial indicators suitable for analyzing the impact of COVID 19 pandemics over the tourism sector}

The financial indicators which will be used to test the companies registered at the Romanian stock market were presented earlier by the author in other studies (Droj, 2012, Droj 2015). Several other authors dealt with analysis of financial indicators in the region: Rozsa (2014), Fenyves et all (2018) Tarnoczi et all(2011) or Karanovic and Karanovic (2016)

As mentioned earlier the indicators selected are representative for the issues of financial efficiency, liquidity and solvency were selected the following indicators:

- Annual return and cash flow- are critical indicators which reflect the evolution of revenues in this sector in the analysed period since the companies are counting on them in order to achieve their survival in a period of economic crisis.

- Number of employees - since one of the most important elements of the tourism sector is the number of jobs created the evolution in number of employees is considered an important element of analysis during an economic crisis.

- Cash flow - is one of the most important elements for companies in periods where

\section{Return Indicators as presented by Droj (2015) and Fenyves et all (2018):}

The Return of Assets (ROA) reflects the difference between an economic result: net profit, known in specialized literature as EBIT and the assets used for its achievement (Pierre, 2004).

$$
\mathrm{ROA}=\frac{\text { Net } \text { Profit }}{\text { Total assets }}
$$

- The Return on Equity (ROE), also known in French economic literature as "financial return rate", and abbreviated in the specialized literature as ROE. This indicator shows the efficiency of the capital invested by shareholders. ROE constitutes one of the most important return indicators, being used by company owners and potential investors in the investment decision-making process.

$$
\mathrm{ROE}=\frac{\text { Net } \text { Profit }}{\text { Equity }}
$$

These indicators were tested by using financial data for companies operating in Tourism industry in Romania, Croatia, Hungary and Slovenia accessed from Amadeus databases (https://amadeus.bvdinfo.com/). The collected information is 
analyzing the Financial Reports of the selected companies in the period 20162020.

\section{The financial performance at the level of the tourism companies operating in Central and Eastern Europe}

The analyzed period (2016-2020) is period when the tourism sector witnessed both growth (2016-2019) and recession caused by COVID 19 in 2020. The companies selected for the study are having the following key financial information: turnover over 1 million EURO and bellow 50 million EURO. The selection used a Boolean algorithm in order to select the most representative tourism companies from Romania, Croatia, , Hungary and Slovenia. The first step of analyzing the impact of COVID 19 over these companies was analyzing the evolution in the period 20162020 of the turnover, cash flow and number of employees.

Table 1 Evolution of turnover, cash flow and number of employees

\begin{tabular}{|l|c|c|c|c|c|}
\hline & $\mathbf{2 0 1 6}$ & $\mathbf{2 0 1 7}$ & $\mathbf{2 0 1 8}$ & $\mathbf{2 0 1 9}$ & $\mathbf{2 0 2 0}$ \\
\hline Turnover (mil. USD) & 12046.5 & 12894.23 & 13955.33 & 15195.87 & 6861.606 \\
\hline Turnover\% evolution & & $7.04 \%$ & $8.23 \%$ & $8.89 \%$ & $-54.85 \%$ \\
\hline Cash flow (mil USD) & 2683.578 & 3006.263 & 3165.479 & 3889.769 & -153.172 \\
\hline Cash flow\% evolution & & $12.02 \%$ & $5.30 \%$ & $22.88 \%$ & $-103.94 \%$ \\
\hline Employees & 212 & 216 & 224 & 228 & 175 \\
\hline Employees\% evolution & & $1.99 \%$ & $3.71 \%$ & $1.53 \%$ & $-23.04 \%$ \\
\hline
\end{tabular}

Source: Calculation of the authors based on the data from

https://amadeus.bvdinfo.com/).

As observed from the Table above the evolution of these indicators was positive each year of the analysis, with an extremely good year of 2019. The COVID-19 impacted heavily the results of 2020 when the values collapsed with $54.85 \%$ in case of turnover, $103.94 \%$ in case of cash flow and $23.04 \%$ in terms of employees.

Figure 3 Evolution of turnover, cash flow and number of employees

Evolution of turnover, cash flow and employees at the regional level

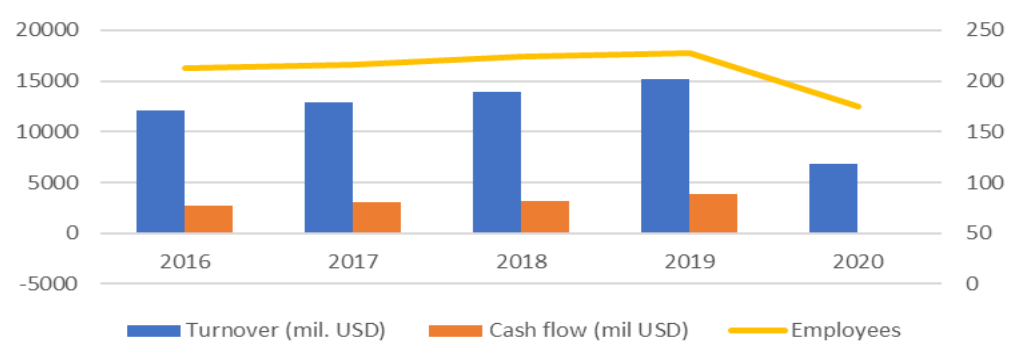

Source: Calculation of the authors based on the data from https://amadeus.bvdinfo.com/). 
The Return on Equity (ROE) was the next indicator which was analyzed for all four countries. As observed from the table bellow, the selected companies from the tourism sector had healthy ROE in the last years. The median of the sector being highest in 2019 at the value of $14.23 \%$ and the average ration of $14.15 \%$, the second highest.

Table 2 Evolution of Return on Equity (ROE) - 2016-2020

\begin{tabular}{|l|r|r|r|r|r|}
\hline ROE(\%) & $\mathbf{2 0 1 6}$ & $\mathbf{2 0 1 7}$ & $\mathbf{2 0 1 8}$ & $\mathbf{2 0 1 9}$ & $\mathbf{2 0 2 0}$ \\
\hline Romania & 31.01 & 18.54 & 20.42 & 20.99 & -2.04 \\
\hline Hungary & 14.90 & 19.61 & 19.33 & 23.23 & -32.17 \\
\hline Slovenia & 10.66 & 8.49 & 0.81 & 4.92 & -3.75 \\
\hline Croatia & 8.31 & 7.44 & 8.79 & 7.46 & -15.30 \\
\hline Median & $\mathbf{1 2 . 7 8}$ & $\mathbf{1 3 . 5 1}$ & $\mathbf{1 4 . 0 6}$ & $\mathbf{1 4 . 2 3}$ & $\mathbf{- 9 . 5 3}$ \\
\hline Mean & $\mathbf{1 6 . 2 2}$ & $\mathbf{1 3 . 5 2}$ & $\mathbf{1 2 . 3 4}$ & $\mathbf{1 4 . 1 5}$ & $\mathbf{- 1 3 . 3 2}$ \\
\hline
\end{tabular}

Source: Calculation of the authors based on the data from https://amadeus.bvdinfo.com/).

The emergence of COVID-19 impacted directly on ROE which plummeted to negative values, the results can be seen clearly in the table bellow. The biggest impact of the COVID-19 over the ROE was registered at the level of Hungarian and Croatian companies, also countries where revenues tourism has an important share in the GDP.

Figure 4 Evolution of Return on Equity (ROE) - 2016-2020

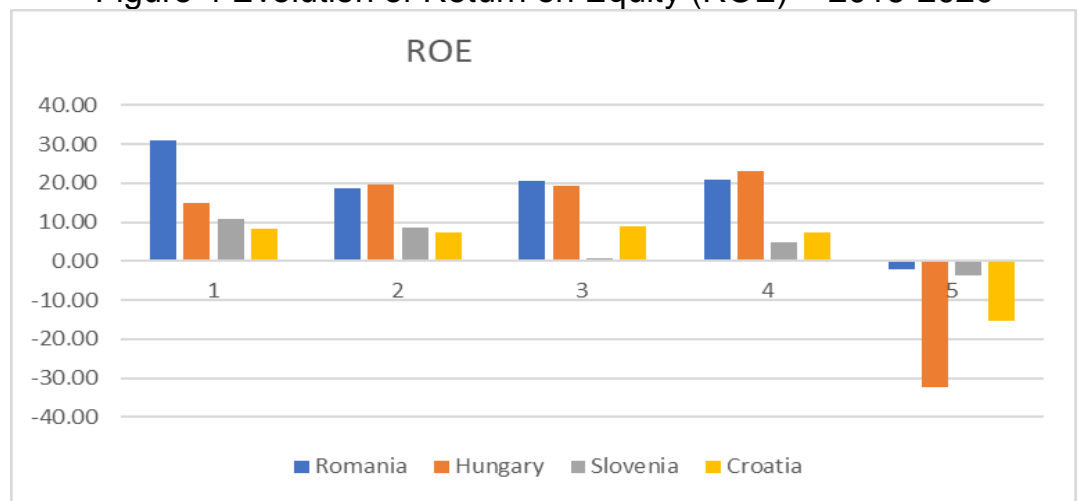

Source: Calculation of the authors based on the data from https://amadeus.bvdinfo.com/).

The evolution of Return of Assets (ROA) was also subjected to negative financial results in 2020 after extremely good years of $2016-2020$ where the results reached from a median of $4.79 \%$ in 2016 to a median of $6.88 \%$ in 2019 . 
Table 3 Evolution of Return on Assets (ROA) - 2016-2020

\begin{tabular}{|l|r|r|r|r|r|}
\hline ROA\% & $\mathbf{2 0 1 6}$ & $\mathbf{2 0 1 7}$ & $\mathbf{2 0 1 8}$ & $\mathbf{2 0 1 9}$ & $\mathbf{2 0 2 0}$ \\
\hline Romania & 5.38 & 7.48 & 8.57 & 10.28 & -1.96 \\
\hline Hungary & 5.98 & 7.37 & 7.43 & 9.66 & -5.49 \\
\hline Slovenia & 4.21 & 3.66 & 1.66 & 1.53 & -4.40 \\
\hline Croatia & 4 & 4 & 4 & 4 & -6 \\
\hline Median & $\mathbf{4 . 7 9}$ & $\mathbf{5 . 6 9}$ & $\mathbf{5 . 5 7}$ & $\mathbf{6 . 8 8}$ & $-\mathbf{4 . 9 4}$ \\
\hline Mean & $\mathbf{4 . 9 4}$ & $\mathbf{5 . 6 3}$ & $\mathbf{5 . 3 4}$ & $\mathbf{6 . 3 9}$ & $\mathbf{- 4 . 4 0}$ \\
\hline
\end{tabular}

Source: Calculation of the authors based on the data from https://amadeus.bvdinfo.com/).

The same as ROE, the evolution of ROA had negative results in 2020 with an median of $-4.94 \%$ and an average of $-4.40 \%$.

Figure 5 Evolution of Return on Assets (ROA) - 2016-2020

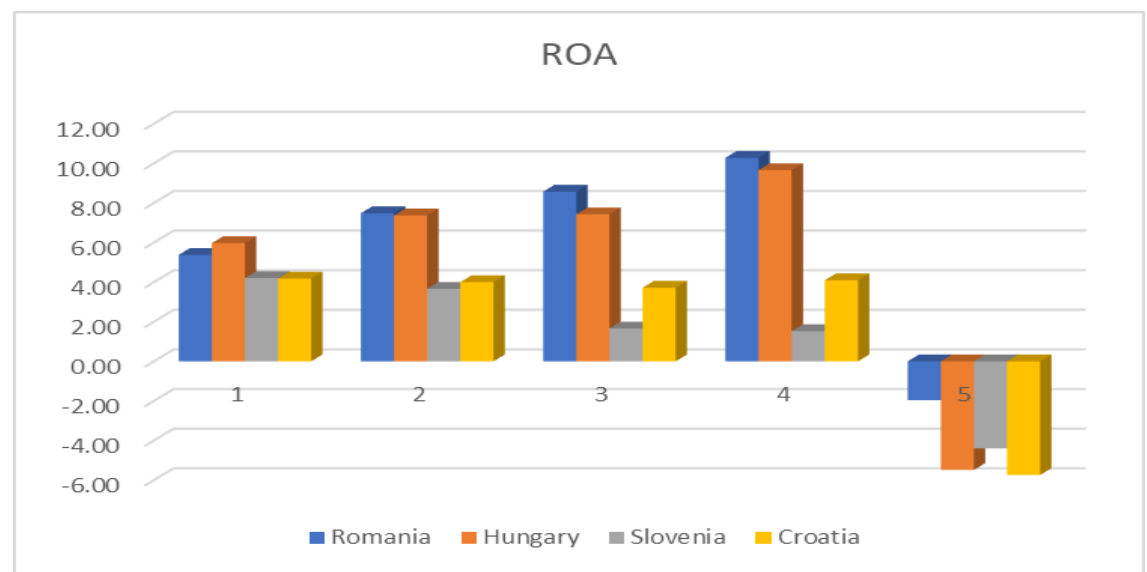

Source: Calculation of the authors based on the data from https://amadeus.bvdinfo.com/).

In 2020, since the effects of COVID-19 were extremely damaging to the revenues, Croatia and Hungary registered the lowest ROA cumulated values in 2020, followed closely by Slovenia.

\section{Conclusions}

As mentioned earlier, the impact of the COVID-19 pandemic over the tourism sectors has been catastrophic both at the level of the financial results (annual return and cash flow), at the level of employed persons in the sector and also at the level the main financial performance indicators. A clear view of the disaster caused in this sector by COVID-19 pandemics can be realized only after the analysis of the financial information for 2021 and the years post-Covid. 
As a general conclusion of the paper we can consider that the indicators used in this study should be accompanied by several other types of indicators both financial, macro-economic, sectorial and also non-financial qualitative or quantitative. This study should be continued on a larger scale and including other indicators in order to establish which elements should be tackled first when dealing with the effects of COVID-19 crisis in order to design the proper measures to revive the tourism sector in Central and Eastern Europe.

\section{References}

1. Amadeus, 2021, Amadeus Database - Software version 16.12 - data update 22.11.2021 https://amadeus.bvdinfo.com/ accessed in 26.11.2021

2. Droj, L., 2012 Financial Performance Analysis based on the Financial Statements for the Companies Located in the Bihor - Hajdu Bihar Euroregion, Published in Annals of the University of Oradea, Economic Science Series;2012, Vol. 21 Issue 2, p464, Oradea, Romania http://connection.ebscohost.com/c/articles/85948972/financial-

performance-analysis-based-financial-statements-companies-located-

bihor-hajdu-bihar-euroregion

3. Droj, L. 2015 Study Regarding the Profitability Indicators for the Romanian Companies Operating in the Tourism and Leisure Services Sector in the Period of 2010-2013 available online at: http://steconomiceuoradea.ro/anale/volume/2015/n1/093.pdf

4. Droj L., Tara I.G., 2018, Early warning indicators - evolution for the medical companies registered at BSE, available online https://ideas.repec.org/a/ora/journl/v1y2018i2p102-108.html

5. Fenyves, Veronika \& Bács, Zoltán \& Zéman, Zoltán \& Böcskei, Elvira \& Tarnoczi, Tibor. (2018). The role of the notes to the financial statements in corporate decision-making. Corporate Ownership \& Control. 15. 138-148. 10.22495/cocv15i4c1p1.

6. Gilbert, L. R., Menon, K., \& Schwartz, K. B. (1990). Predicting bankruptcy firms in financial distress. Journal of Business, Finance \& Accounting, 17(1), 161-171.

7. Goran Karanovic, Bisera Karanovic, and Martina Gnjidic. 2018. Liquidity Risk Management: Practice Among Croatian Firms. Journal of the Polytechnic of Rijeka, 6(1), 81-98.

8. Karanovic, Goran, and Bisera Karanovic. 2016. IPOs Performance Analysis: Evidence from Emerging Markets in the Balkans. Scientific Annals of Economics and Business 63(3): 381-389. DOI: 10.1515/saeb2016-0129

9. Ohlson, J. A. (1980). Financial ratios and the probabilistic prediction of bankruptcy. Journal of Accounting Research 18(1), 109-131. 
10. Pierre F., (2004), Valorisation d'entreprise et theorie financiere, Edition d'Organisation, Paris, p. 25, France

11. Rozsa, A. (2014), Financial position of building industry in Hajdú-Bihar county (E-Hungary) in the period of 2008-2012: Regional sectoral analysis based on economic performance ratios, published in International Review Of Applied Sciences And Engineering 5:(1) pp. 67-77, http://www.akademiai.com/doi/abs/10.1556/IRASE.5.2014.1.9

12. Statista Research Department, 2021, Travel and tourism in Europe statistics \& facts, available online at https://www.statista.com/topics/3848/travel-and-tourism-ineurope/\#dossierKeyfigures

13. Tarnoczi, Tibor \& Fenyves, Veronika. (2011). Liquidity management and corporate risk. Annals of Faculty of Economics. 1. 530-536.

14. United Nations 2021, Coronavirus pandemic could cost global tourism \$2 trillion this year, available online https://news.un.org/en/story/2021/11/1106712

15. UNWTO, 2021, Global Tourism Sees Upturn in Q3 but Recovery Remains Fragile, available online at https://www.unwto.org/news/global-tourismsees-upturn-in-q3-but-recovery-remains-fragile 